\title{
Soil physico-hydrical properties resulting from the management in Integrated Production Systems ${ }^{1}$
}

\author{
Propriedades físico-hídricas do solo decorrentes do manejo em Sistemas Integrados \\ de Produção
}

\author{
André Carlos Auler²*, Simone Miara², Luiz Fernando Pires², Adriel Ferreira da Fonseca² e Gabriel Barth ${ }^{3}$
}

\begin{abstract}
Anthropic action, such as the soil use and management systems, promote changes in the soil structure. These changes might hamper the development of plants in soil management practices that involve its mobilization, and the negative effects might be increased due to intensive use. The aim of this study was to evaluate the physico-hydrical properties of a Haplohumox in integrated production systems under different soil managements. The soil superficial $(0.0-0.10 \mathrm{~m})$ and subsuperficial $(0.10-0.20 \mathrm{~m})$ layers were evaluated in the different systems: conventional tillage (CT), minimum tillage (MT), no-tillage (NT) and chiseled no-tillage (CNT), taking into consideration the annual ryegrass cropped for different uses [cover crop (C), grazing $(\mathrm{G})$ and silage (S)] during the winter. Soil bulk density (Db), total porosity (TP), macro (Ma) and microporosity $(\mathrm{Mi})$, water retention curves (SWRC) and water retention due to pore size (r) were determined. The annual ryegrass used as $\mathrm{C}$ produced lower $\mathrm{Db}$ and $\mathrm{Mi}$ and higher TP and Ma in CT, MT and CNT systems. No difference was verified between $\mathrm{G}$ and $\mathrm{S}$ in any of the management systems or soil layers. The superficial layer SWRC presented similar behavior regarding CT, MT and CNT. Under NT, C resulted in higher water retention. However, G and S provided higher water retention due to the pore size in this system.
\end{abstract}

Key words: Haplohumox. No-tillage. Soil physical quality. Crop-livestock integration. Agriculture sustainability.

\begin{abstract}
RESUMO - As ações antrópicas, como os sistemas de uso e manejo do solo, promovem alterações em sua estrutura. Estas alterações podem ser restritivas ao desenvolvimento das plantas em manejos do solo que envolva sua mobilização, tendo seus efeitos negativos potencializados pela maior intensificação de uso. O objetivo deste trabalho foi avaliar os atributos físico-hídricos de um Latossolo Bruno argiloso em sistemas integrados de produção sob distintos manejos de solo. Para isso avaliou-se a camada superficial (0.0-0.10 m) e subsuperficial (0.10-0.20 m) do solo nos sistemas de cultivo convencional (CT), mínimo (MT), plantio direto (NT) e plantio direto escarificado (CNT) sob diferentes usos da cultura do azevém [planta de cobertura (C), pastejo (G) e silagem (S)]. Determinou-se a densidade (Db), porosidade total (TP), macro (Ma) e microporosidade (Mi), as curvas de retenção de água (CRA) e a retenção de água em função do raio de poro (r). O uso do azevém como C proporcionou menores Db e Mi e maiores TP e Ma nos sistemas CT, MT e CNT. Não foram verificadas diferenças entre G e S para todos os manejos, em ambas as camadas de solo. As CRA da camada superficial entre CT, MT e CNT apresentaram comportamento semelhante. No NT, C proporcionou uma maior retenção de água. Entretanto, G e S proporcionaram maior a retenção de água em função dos raios de poros no NT.
\end{abstract}

Palavras-chave: Latossolo Bruno. Plantio direto. Qualidade física do solo. Integração lavoura-pecuária. Sustentabilidade agrícola.

\footnotetext{
*Autor para correspondência

Recebido para publicação em 10/05/2014; aprovado em 23/09/2014

Parte da Dissertação de Mestrado da segunda autora, apresentado ao Programa de Pós-Graduação em Agronomia da Universidade Estadual de Ponta Grossa/UEPG, Ponta Grossa-PR

${ }^{2}$ Programa de Pós-Graduação em Agronomia/UEPG, Campus Uvaranas, Av. Gal. Carlos Cavalcanti 4748, Ponta Grossa-PR, Brasil, 84.030-900, aulerac@gmail.com, simonemiara@gmail.com, luizfpires@gmail.com, adrielff@gmail.com

${ }^{3}$ Fundação ABC Pesquisa e Desenvolvimento Agropecuário, Rodovia PR 151, Km 288, Caixa Postal 1003, Castro-PR, Brasil, 84.166-981, gabrielbarth@fundacaoabc.org.br
} 


\section{INTRODUCTION}

The world population increase has led to the use of more modern technologies to produce food. As a consequence, the use of soil is intensified and makes it susceptible to degradation. Therefore, more sustainable productive systems, such as integrated production systems, which aim at higher economical efficacy and lower environmental impact, are necessary (DORAN et al., 1994; LAL, 1998).

Among integrated systems, animal breed associated to grain production areas, called crop-livestock integration has been widely developed. However, cattle trampling often provoke negative changes to the soil structure, mainly in its superficial layer (DREWRY et al., 2008). One alternative to reduce the trampling impact would be to cut the forage and feed it to the animals in the trough, as in the ensiling and haying. However, the pressure on the soil, through heavy traffic and the agriculture machinery mass in order to cut the plants might also result in soil compaction (BAVOSO et al., 2010).

Agriculture sustainability does not depend exclusively on the soil; it also depends on soil management (DORAN et al., 1994; LAL, 1998). Management systems affect the soil structure, and consequently, its porous space and physico-hydrical properties (BRONICK; LAL, 2005; LIPIEC et al., 2006). Therefore, studies on the soil physical properties, related to its structure and water retention are relevant, mainly in conditions that involve higher intensification of soil use, as in the integrated production systems.

No-tillage (NT) has been a production system characterized by the absence of soil mechanic disturbance, soil permanent covering by crop residues and crop rotation which improve the soil structure (BETIOLI JÚNIOR et al., 2012). However, not revolving the soil and exposing it to the machinery traffic in unsuitable humidity conditions result in its compaction, a problem which has been commonly reported in NT (BATEY, 2009; HAMZA; ANDERSON, 2005).

In such context, the soil scarification has been presented as a soil and water conservationist technique in NT, originating the concept of chiseled no-tillage (CNT), which promotes improvement to the soil physical properties (CAMARA; KLEIN, 2005). However, discussion has still been held about the persistence of the beneficial effects of this practice (GIRARDELLO et al., 2011). Soil mobilization in NT through scarification is reduced when compared to other soil preparation methods, such as plowing and harrowing, used in conventional (CT) and minimum cultivation (MT) management systems (FALLEIRO et al., 2003).

Despite the increase in soil macroporosity through the mobilization, either in CT, MT or CNT, the formation of compacted layers occurs after some time (REICHERT; SUZUKI; REINERT, 2007), which alters the porous space and, consequently, water retention processes (LIPIEC et al., 2006). Therefore, the soil physicohydrical properties might restrict plant development in soil management systems that involve its mobilization, resulting in higher negative effects. Taking that into consideration, the aim of this study was to evaluate the physico-hydrical properties of a Haplohumox in integrated production systems under different soil managements.

\section{MATERIAL AND METHODS}

\section{Location, characterization and development of the experiment}

The experiment was carried out in Castro/PR (latitude: 244' 57' S; longitude: 49 57' 41' ' W; altitude: $997 \mathrm{~m}$ ), in a Haplohumox "Latossolo Bruno" by the Brazilian Soil Classification System, according (SANTOS et al., 2013), whose chemical and granulometric properties prior to the experiment can be seen in Table 1 .

The climate in this region, according to the Köppen classification is $\mathrm{Cfb}$, with the coldest month average temperature below $18^{\circ} \mathrm{C}$ and the hottest month below $22^{\circ} \mathrm{C}$, with frequent frost events (mesothermal), mild summers and undefined dry season. The average annual rainfall is between 1600 and 1800 mm (IAPAR, 2009). In Figure 1, it can be seen that since the experiment installation occurred water surplus, however, in the months of August and September, there was a large frequency of hydric deficit.

When the experiment started (March 2004) 5.36 $\mathrm{Mg} \mathrm{ha}^{-1}$ lime was applied to the soil and, in March 2009, $8.36 \mathrm{Mg} \mathrm{ha}^{-1}$ of the same material was reapplied. The application method varied according to the management system. From the beginning of the experiment, a succession of annual ryegrass (Lolium multiflorum L.)/ maize (Zea mays L.) crops was employed.

The experiment was carried out in bands with treatment of subdivided plots, in four replications. The bands presented an area of $1200 \mathrm{~m}^{2}(120 \times 10 \mathrm{~m})$ and the subplots $100 \mathrm{~m}^{2}(10 \times 10 \mathrm{~m})$. The bands were under different management systems: conventional (CT), minimum tillage (MT), no-tillage (NT) and chiseled no-tillage (CNT). In the sub-plots, the annual ryegrass use was cropped as follows: cover crop $(\mathrm{C})$; grazing $(\mathrm{G})$ and silage $(\mathrm{S})$.

Soil preparation operations, from the beginning of the experiment were carried out prior to the winter crop sowing, annually under CT and MT and every two years under CNT. In the CT only one plowing was carried out at $0.20 \mathrm{~m}$, with a disk plow, followed by two harrowing 
Table 1 - Soil chemical properties and granulometry before the beginning of the experiment (March 2004)

\begin{tabular}{|c|c|c|c|c|c|c|c|}
\hline Layer & \multirow{2}{*}{$\mathrm{pH}\left(\mathrm{CaCl}_{2}\right)$} & $\mathrm{H}+\mathrm{Al}$ & $\mathrm{Al}$ & $\mathrm{Ca}$ & $\mathrm{Mg}$ & $\mathrm{K}$ & $\mathrm{CEC}$ \\
\hline $\mathrm{m}$ & & ----------. & ----------. & ---- mmo & $\mathrm{dm}^{-3}$ & $\cdots$ & - \\
\hline $0.0-0.10$ & 4.7 & 72 & 1 & 37 & 10 & 4.8 & 132.2 \\
\hline \multirow[t]{3}{*}{$0.10-0.20$} & 4.6 & 72 & 2 & 22 & 8 & 2.7 & 104.7 \\
\hline & $\mathrm{P}$ & $\mathrm{OC}$ & $\mathrm{V}$ & $\mathrm{m}$ & Clay & Silt & Sand \\
\hline & $\mathrm{mg} \mathrm{dm}{ }^{-3}$ & $\mathrm{~g} \mathrm{dm}^{-3}$ & - - & ---------- & 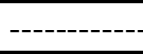 & $\mathrm{g} \mathrm{kg}^{-1}$ & - \\
\hline $0.0-0.10$ & 85 & 29 & 42 & 1.92 & 439 & 384 & 177 \\
\hline $0.10-0.20$ & 44 & 24 & 31 & 5.76 & 488 & 357 & 155 \\
\hline
\end{tabular}

$\mathrm{H}+\mathrm{Al}$ - Potential acidity; $\mathrm{Al}, \mathrm{Ca}, \mathrm{Mg}, \mathrm{K}$ - exchangeable aluminum, calcium, magnesium and potassium, respectively; CEC - Cation exchange capacity; $\mathrm{P}$ - Phosphorus available (Melich-1); OC - organic carbon by Walkley-Black method; V - base-saturation, $\mathrm{m}$ - aluminum saturation

Figure 1 - Sequential hydric balance* (SHB), by using potential evapotranspiration by the Penman-Monteith method, in the city of Castro (PR) - Brazil, measured from May 2005 to October 2012. *Obtained from the Agrometerological Monitoring System (smaABC) database of the ABC Foundation, located $10 \mathrm{~km}$ far the experimental area

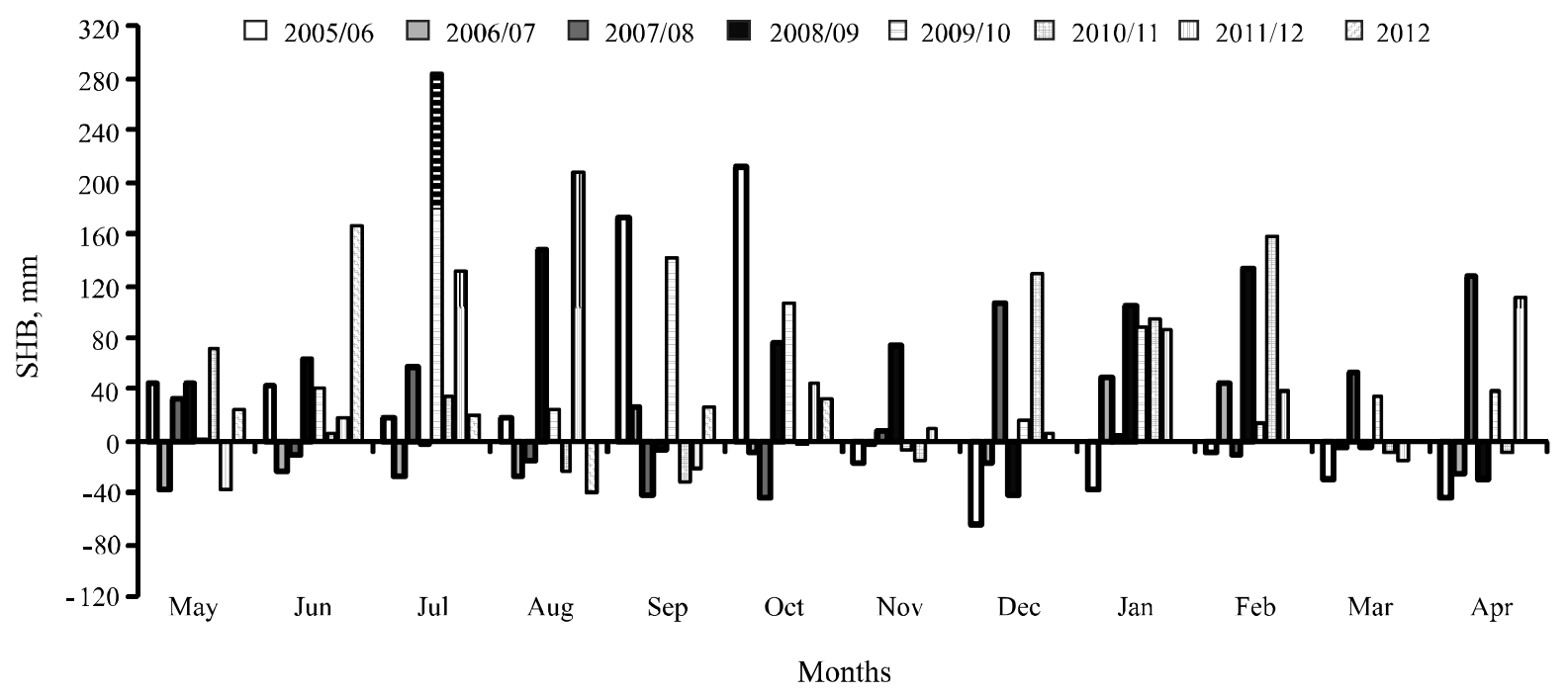

sessions with a leveling harrow. In MT only one harrowing at $0.10 \mathrm{~m}$ with a leveling harrow was carried out. In CNT, chiseled was carried out at $0.25 \mathrm{~m}$, with moldboard plow and $0.60 \mathrm{~m}$ space between the tines. Annual ryegrass sowing was carried out in early May, with the aid of a notillage multiple seeder-fertilizer, using $60 \mathrm{~kg}$ seeds $\mathrm{ha}^{-1}$, with $0.17 \mathrm{~m}$ between lines and $0.03 \mathrm{~m}$ depth.

Cuts for silage or grazing started when the annual ryegrass reached around $0.30 \mathrm{~m}$ height. Plant cuts for the pre-dried silage were carried out at $0.10 \mathrm{~m}$ high with an ensiling machine. The continuous grazing system was adopted with loading rate of $1,350 \mathrm{~kg} \mathrm{ha}^{-1}$ of live weight, and 7 days occupancy time or until the forage residue reached $0.10 \mathrm{~m}$ high. After the last cut and grazing the forage was stockpiled for a period of 20 days and then desiccated for the next crop (maize) sowing.

\section{Sampling, analyses and data adjustment}

In October 2012, after the annual ryegrass phytomass management, undisturbed soil samples $(0.0$ $0.10 \mathrm{~m}$ and $0.10-0.20 \mathrm{~m})$ were collected in stainless steel volumetric rings $(\approx 0.05 \times \approx 0.05 \mathrm{~m}$ - external diameter and height) aided by a Uhland sampler. Five pseudo-replications were collected in the subplots of the one of the experiment replications, with the aim to reduce the spatial variability of soil properties due to the experimental area size.

Disturbed samples were collected from the same layers near the undisturbed sample collection area with the aid of a soil auger. These samples were then submitted to analyses: granulometric (hydrometer method), particle density (pycnometer method) (DANE et al., 
2002) and organic carbon (OC) (Walkley-Black method) (CANTARELLA et al., 2001).

After thorough preparation, the undisturbed samples were saturated by the capillarity rise method and submitted to the matric potential $(\Psi \mathrm{m})$ from -1 to $10 \mathrm{kPa}$, on a tension table to assess the partial water retention curves $(\mathrm{SWRC})$. After drying $\left(105^{\circ} \mathrm{C} / 24 \mathrm{~h}\right)$, soil water content $\left(\theta, \mathrm{m}^{3} \mathrm{~m}^{-3}\right)$, bulk density $\left(\mathrm{Db}, \mathrm{Mg} \mathrm{m}^{-3}\right)$, total porosity (TP, $\mathrm{m}^{3} \mathrm{~m}^{-3}$ ) as well as microporosity (Mi, $\left.\mathrm{m}^{3} \mathrm{~m}^{-3}\right)$ and macroporosity $\left(\mathrm{Ma}, \mathrm{m}^{3} \mathrm{~m}^{-3}\right)$ were determined (DANE et al., 2002; EMBRAPA, 1997).

Water retention curves were adjusted following the van Genuchten model (1980) (Equation 1), with the Mualem restriction (1986) (Equation 2):

$$
\begin{aligned}
& \theta=\theta r+\frac{(\theta s-\theta r)}{\left[1+(\alpha \Psi m)^{r}\right]^{m}} \\
& m=1-\left(\frac{1}{n}\right)
\end{aligned}
$$

where $\theta \mathrm{s}$ and $\theta \mathrm{r}$ are the water saturation and residual contents $\left(\mathrm{m}^{3} \mathrm{~m}^{-3}\right)$, respectively; $\Psi \mathrm{m}$ the soil matric potential ( $\mathrm{kPa})$; and, $\alpha, m$ and $n$ the adjustment equation empirical parameters determined by the software SWRC Fit (SEKI, 2007).

The van Genuchten model was employed to obtain the SWRC up to the potential regarding the permanent wilting point $(-1500 \mathrm{kPa})$. After obtaining the SWRC, water content data was simulated for different $\Psi \mathrm{m}$ values. From this data, relative difference (RD) values were obtained between the water content value for different $\Psi \mathrm{m}$ aiming to make the SWRCs analysis for the different uses of annual ryegrass easier:

$$
R D=\left(\frac{\theta 1-\theta 2}{\theta 1}\right) .100
$$

(Equation 3)

where $\theta 1$ and $\theta 2$ are the water content for the different uses of annual ryegrass, for example, 1 for cover and 2 for grazing.

From the SWRC data, graphs regarding the water retention for different pore sizes (Equation 4) were also created. Water retention was calculated by subtracting the water content total porosity for the different potentials used in the SWRC construction. Equation 4 was used to obtain the pores radius:

$r=\frac{1490}{h}$

(Equation 4)

where $r$ represents pore size in $\mu \mathrm{m}$ and $\mathrm{h}$ the matric potential in $\mathrm{cm}$ of water column.

\section{Statistical analyses}

A totally randomized experiment statistical model was employed with treatment in split-splot bands, considering the management systems in the bands and the annual ryegrass management in the subplots, for analysis of variance. The residue normality and homoscedasticity assumptions were verified employing the Shapiro-Wilk and Bartlett tests, respectively. Whenever necessary, the Tukey test was applied to compare the averages. All interfering procedures were carried out considering the $5 \%$ level of significance. Statistical analyses were processed aided by the software R, version 3.0.2 (R CORE TEAM, 2013).

\section{RESULTS AND DISCUSSION}

\section{Bulk density, total porosity, and soil microporosity and macroporosity}

$\mathrm{Db}, \mathrm{TP}$ and $\mathrm{Ma}$ in the superficial layer (0.0$0.10 \mathrm{~m}$ ) were influenced by the soil management systems, by the annual ryegrass use and their interaction (Table 2). No differences were observed for $\mathrm{Db}, \mathrm{TP}$ and Ma between the annual ryegrass use for grazing and silage in any of the management systems. However, in NT the use as cover did not differ from the grazing or silage (Figures $2 \mathrm{a}, 2 \mathrm{c}$ and $2 \mathrm{e}$ ).

$\mathrm{Db}, \mathrm{TP}$ and $\mathrm{Ma}$ in the superficial layer showed no differences between the annual ryegrass different uses only in NT and, for the other soil management system, grazing and silage were higher for $\mathrm{Db}$ and lower for TP and Ma (Figure 2), which might be a result of: (i) higher pressure on the soil due to heavier machinery traffic to produce the silage (FREDDI et al., 2007); (ii) animal trampling during grazing practices (BELL et al., 2011; DREWRY et al., 2008); and (iii) reduced soil preparation in NT (REICHERT; SUZUKI; REINERT, 2007; VEIGA et al., 2007).

In NT there is higher OC accumulation in the surface, positively influencing the soil structure (BRONICK; LAL, 2005). Silva et al. (2006) observed the negative correlation between OC content and $\mathrm{Db}$ and the positive one with TP in a sandy-clay-loam Alfisol under different uses and management. However, when compared to the management systems for the annual ryegrass as cover crop, it can be seen that NT, with higher OC content (Figure $3 g$ ) represented higher $\mathrm{Db}$ and lower TP and Ma in its superficial layer (Figure 2a, $2 \mathrm{c}$ and $2 \mathrm{e}$ ). In this case it is likely that the increase in Db and decrease in Ma reduced the soil aeration condition, decreasing its microbial activity and consequently the residue decomposition, which in turn resulted in OC accumulation (BATEY, 2009; COSTA et al., 2009). 
Table 2 - Summary's analysis of variance of the soil bulk density (Db); total porosity (TP), macroporosity (Ma) and microporosity (Mi) of a Haplohumox from the 0.0-0.10 m and 0.10-0.20 m layers due to soil management systems (SMS) and the use of annual ryegrass (UR)

\begin{tabular}{lccccccccc}
\hline \multirow{2}{*}{ Variance's sources } & d.f. & \multicolumn{7}{c}{ Mean squares } \\
\cline { 3 - 10 } & & $\mathrm{Db}$ & $p$ & $\mathrm{TP}$ & $p$ & $\mathrm{Ma}$ & $p$ & $\mathrm{Mi}$ & $p$ \\
\hline SMS & 3 & 0.0152 & 0.0118 & 0.0022 & 0.0110 & 0.0054 & 0.0233 & 0.0008 & 0.1108 \\
Error - a & 16 & 0.0030 & & 0.0004 & & 0.013 & & 0.0004 & \\
UR & 2 & 0.0110 & $<0.0001$ & 0.0158 & $<0.0001$ & 0.0388 & $<0.0001$ & 0.0053 & $<0.0001$ \\
SMS*UR & 6 & 0.0077 & 0.0054 & 0.0011 & 0.0050 & 0.0042 & 0.0025 & 0.0011 & 0.0192 \\
Error - b & 32 & 0.0020 & & 0.0003 & & 0.0010 & & 0.0004 & \\
C.V. (\%) SMS & & 4.6 & & 3.8 & & 36.5 & & 4.2 & \\
C.V. (\%) UR & & 3.8 & & 3.1 & & 31.4 & & 4.2 & \\
\hline & & & & & $0.10-0.20$ m layer & & & \\
\hline SMS & 3 & 0.0084 & 0.0721 & 0.0012 & 0.0715 & 0.0013 & 0.2270 & $<0.0001$ & 0.9575 \\
Error a & 16 & 0.0030 & & 0.0004 & & 0.0008 & & 0.0002 & \\
UR & 2 & 0.0038 & 0.2179 & 0.0005 & 0.1994 & 0.0004 & 0.6523 & 0.0003 & 0.6027 \\
SMS*UR & 6 & 0.0068 & 0.0242 & 0.0010 & 0.0162 & 0.0030 & 0.0167 & 0.0010 & 0.1179 \\
Error b & 32 & 0.0024 & & 0.0003 & & 0.0010 & & 0.0005 & \\
C.V. (\%) SMS & & 4.4 & & 3.8 & & 30.1 & & 2.9 & \\
C.V. (\%) UR & & 3.9 & & 3.3 & & 32.9 & & 5.2 & \\
\hline
\end{tabular}

d.f.- degrees of freedom; $p$ - probability; SMS*UR - Interaction between soil management systems and annual ryegrass use; C.V. - coefficient of variation

The sub-superficial layer $(0.10-0.20 \mathrm{~m}) \mathrm{Db}$, TP and Ma differed significantly only for the annual ryegrass use as cover crop. For this use of annual ryegrass, CNT and MT presented the lowest and the highest $\mathrm{Db}$, respectively. NT and CT did not differ one from another. However, NT was different from CNT and CT from MT (Figure 1b). An inverse $\mathrm{Db}$ relation was obtained in TP in this layer (Figure 2d). For Ma, MT and NT there was no difference and these were lower than CNT. For this variable, CT was similar as the other management systems (Figure 2f).

Considering that CT and MT presented similar soil mobilization, even though it was minimal, the more likely reason for the difference found between these systems is the cut depth during soil preparation. The plowing operation employed in CT promotes the soil superficial layer inversion, while harrowing in MT only mobilizes the surface (FALLEIRO et al., 2003). Thus, in MT the formation of compacted layers in the surface have outstood, which increased Db with consequent TP reduction (REICHERT; SUZUKI; REINERT, 2007).

There were also differences in Db and TP $(0.10$ $0.20 \mathrm{~m}$ ) in the management systems which promoted lower soil mobilization (NT and CNT). Db and TP in NT are a consequence of the pressure on the soil produced by crop management practices along the years of cultivation (BATEY, 2009; HAMZA; ANDERSON, 2005). For CNT, in which there was soil mobilization at $0.25 \mathrm{~m}$ depth, there was reduction in $\mathrm{Db}$ and increase in TP (Figure 2b).

The sub-superficial layer $\mathrm{Db}, \mathrm{TP}$ and $\mathrm{Ma}$ regarding annual ryegrass uses in CT, MT and NT did not present difference. In CNT the highest and lowest Db were obtained with annual ryegrass used as grazing and cover crop, respectively, while the silage annual ryegrass was equal to those uses (Figure 2b). TP did not differ between the annual ryegrass uses for grazing and silage and, these were lower than the cover one (Figure 2d). This layer Ma had an inverse Db relation, that is the use of annual ryegrass as cover crop and grazing resulted in the highest and the lowest Ma, respectively, and the use as silage was similar to them (Figure 2f).

Such results indicate that the animal trampling, mainly, and machinery traffic on the soil in CNT altered its sub-surface structure. It is important to highlight that the results of soil management systems resulting from animal trampling, obtained in this work, are different from what has been commonly reported in the literature (BATEY, 2009; BELL et al., 2011; DREWRY et al., 2008; HAMZA; ANDERSON, 2005; KUNZ et al., 2013; SILVA et al., 2011), revealing the need for studies on soil management in integrated production systems. 
Figure 2 - Bulk density (a,b), total porosity (c, d), macroporosity (e,f) and microporosity (g,h) from the superficial (0.0-0.10 m) and sub-superficial (0.10-0.20 m) layers of a Haplohumox due to soil management system [conventional (CT), minimum (MT), no-tillage (NT) and chiseled no-tillage (CNT)] and the winter crop use [cover crop (C), grazing (G) and silage (S)]. LSD = least significant difference by Tukey test $(\mathrm{p} \leq 0.05)$. SMS = soil management system. UR $=$ Use of annual ryegrass
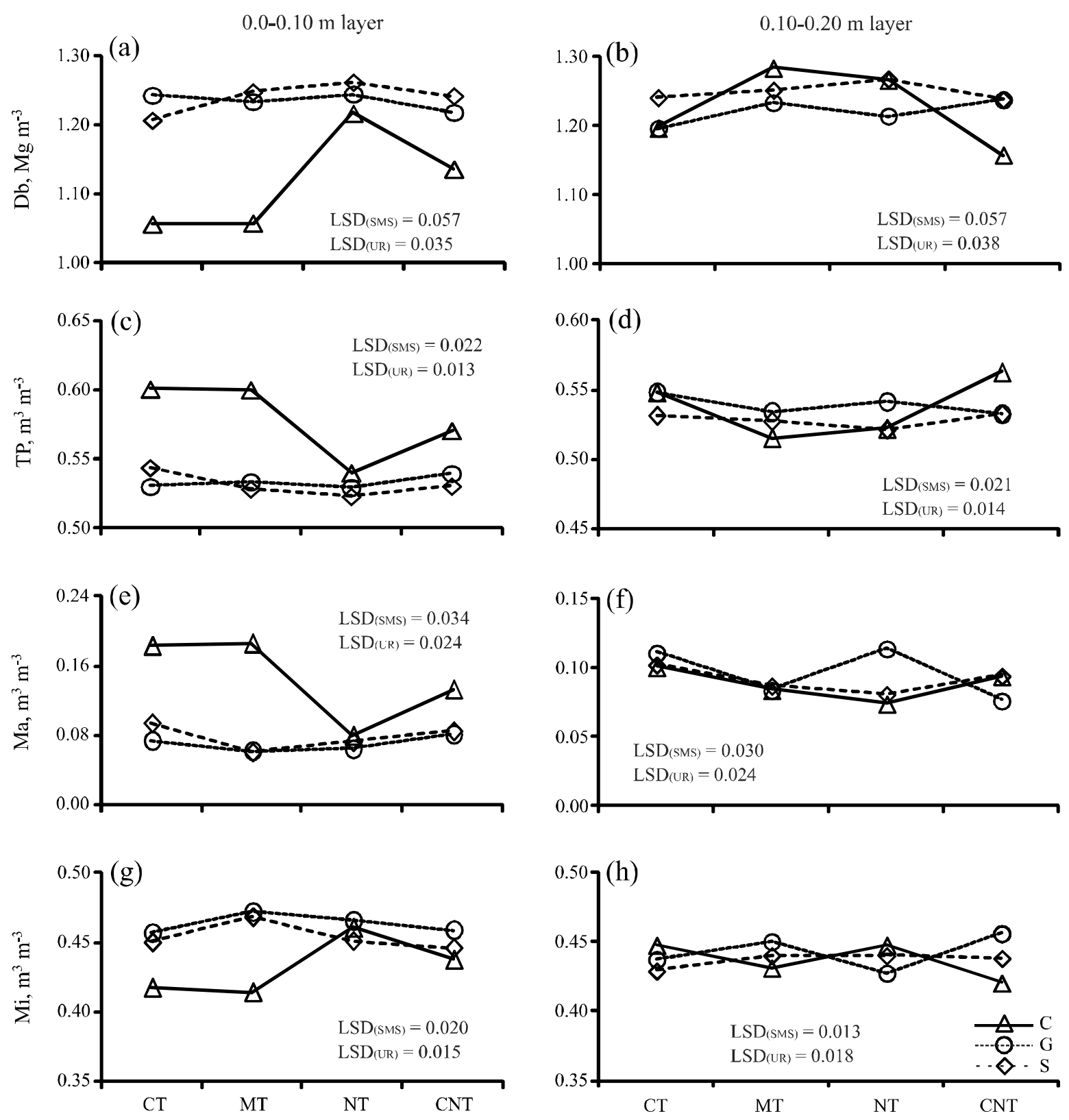

Soil management system

The superficial layer Mi was not affected by the soil management system, but it was mainly by the annual ryegrass use and, in lower proportion, by its interaction with the management system (Table 2). Regarding the uses, there was no difference between grazing and silage, and these were higher than those for cover crop in the management systems which involve higher soil mobilization (CT and MT). In NT and CNT systems, there was no difference in the superficial layer Mi when the annual ryegrass uses were taken into consideration. However, Mi presented differences regarding the annual ryegrass use as cover crop, in which in NT it was higher than in CT and MT while in CNT it was the same as the other systems (Figure 2g). 
Figure 3 - Sand (a, b); silt (c, d); clay (e, f) and organic carbon (g,h) contents from the superficial (0.0-0.10 m) and subsuperficial (0.10-0.20 m) layers of a Haplohumox due to soil management system [conventional (CT), minimum (MT), notillage (NT) and chiseled no-tillage (CNT)] and the winter crop use [cover crop (C), grazing (G) and silage (S)]
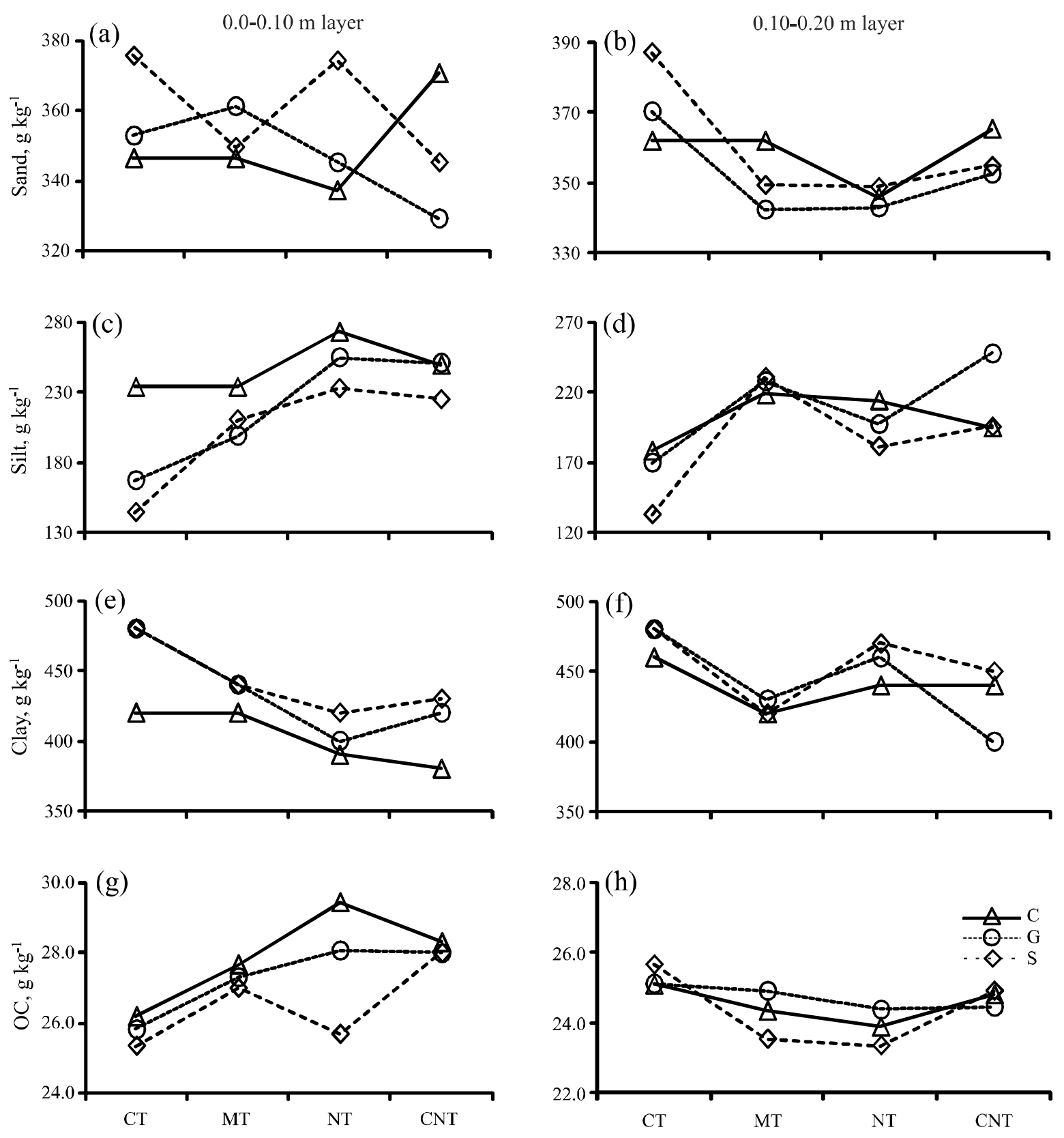

Soil management system

Management systems, annual ryegrass uses and the interaction between them did not influence the sub-superficial layer (Table 2). Lanzanova et al. (2007) verified the absence of changes in $\mathrm{Mi}$ in an Alfisol clay-loam under different grazing intensity in NT. Viana et al. (2011) obtained similar results in a sandy-loam Oxisol for different soil uses. Therefore, results obtained in this work reinforce that $\mathrm{Ma}$ is the TP fraction more susceptible to changes in the soil use and management, mainly due to the increase in $\mathrm{Db}$. This effect can be ascribed to the fact that Mi suffers very little influence of the $\mathrm{Db}$ increase, but is strongly influenced by the OC content and texture (SILVA; KAY, 1997). 


\section{Water retention in the soil}

Water content, in high $\Psi \mathrm{m}$, in the superficial layer $(0.0-0.10 \mathrm{~m})$ regarding CT, MT and CNT systems was higher when the annual ryegrass was used as cover crop (Figures $4 \mathrm{a}, 4 \mathrm{c}$ and $4 \mathrm{~g}$ ). Results related to higher TP and Ma and lower Db were obtained in this use of annual ryegrass (Figures $2 \mathrm{a}, 2 \mathrm{c}$ and $2 \mathrm{~g}$ ). In a completely saturated soil $\theta \mathrm{s}=\mathrm{TP}$ is found (DANE et al., 2002; MACHADO et al., 2008; MICHELON et al., 2010). Depending on the soil pore distribution, which is related to its structure and texture, the SWRC inflection point will present distinct values. This inflection point can be related to the parameter $n$ in the van Genuchten

Figure 4 - Water retention curves from the superficial (0.0-0.10 m) and sub-superficial (0.10-0.20 m) layers of a Haplohumox due to soil management system [conventional (a,b), minimum (c,d), no-tillage (e,f) and chiseled no-tillage (g,h)] and the winter crop use [cover crop $(\mathrm{C})$, grazing $(\mathrm{G})$ and silage $(\mathrm{S})$ ]
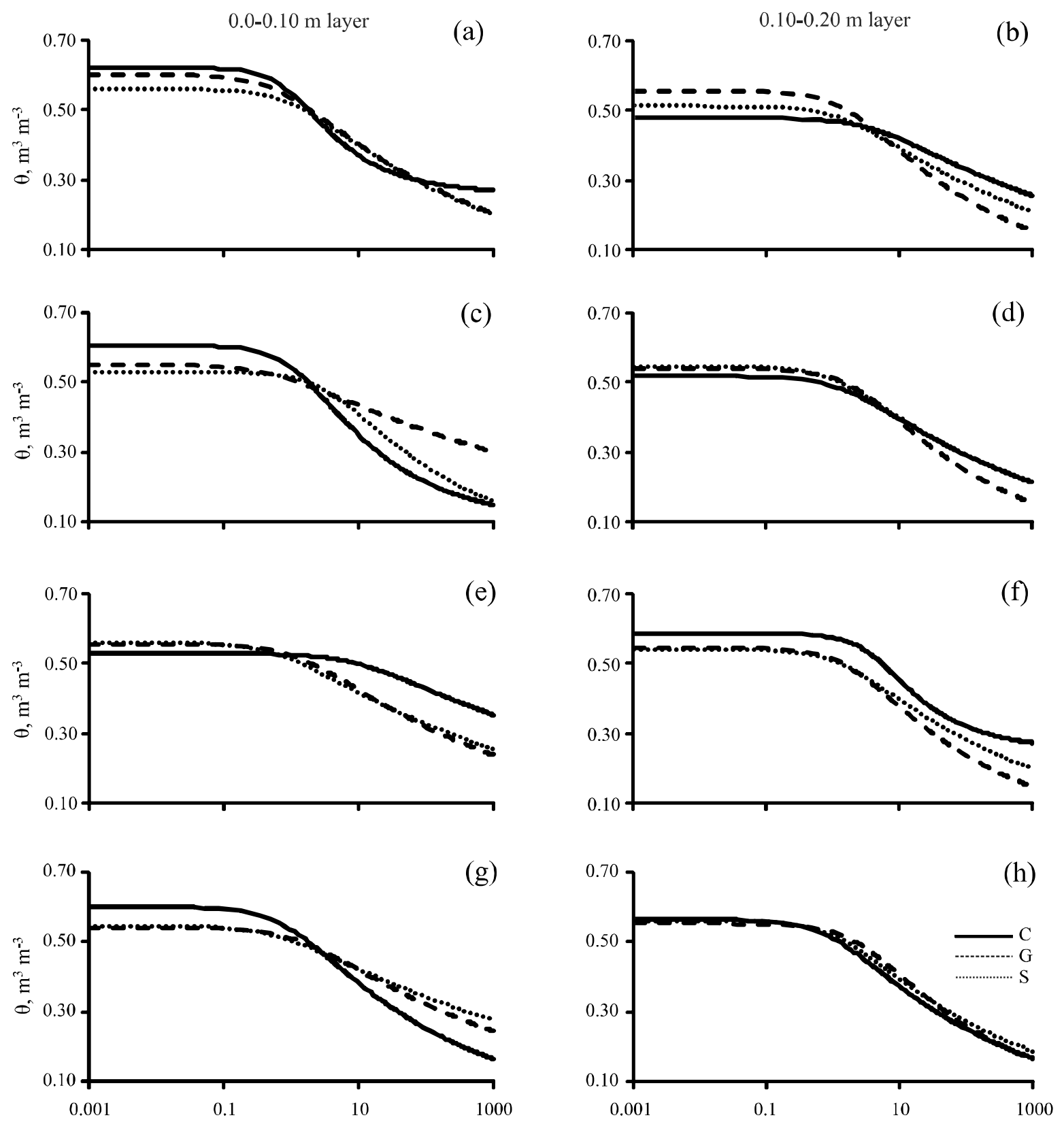

$-\Psi_{\mathrm{m}, \mathrm{kPa}}$ 
Table 3 - Water retention curve parameters and regression determination coefficient, adjusted through the van Genuchten (1980) mathematical model, for the superficial (0.0-0.10 m) and sub-superficial (0.10-0.20 m) layers of a Haplohumox due to soil management system [conventional (CT); minimum (MT), no-tillage (NT) and chiseled no-tillage (CNT)] and the winter crop use [cover crop $(\mathrm{C})$, grazing $(\mathrm{G})$ and silage $(\mathrm{S})]$

\begin{tabular}{|c|c|c|c|c|c|c|c|c|}
\hline \multirow{2}{*}{ SMS } & \multirow{2}{*}{ UR } & Layer & $\theta \mathrm{s}$ & $\theta \mathrm{r}$ & $\alpha$ & \multirow{2}{*}{$\mathrm{n}$} & \multirow{2}{*}{$\mathrm{m}$} & \multirow{2}{*}{$\mathrm{R}^{2}$} \\
\hline & & $\mathrm{m}$ & 1---------- & $\mathrm{m}^{-3}-$ & $\mathrm{kPa}^{-1}$ & & & \\
\hline \multirow{6}{*}{ CT } & \multirow{2}{*}{$\mathrm{C}$} & $0.0-0.10$ & 0.6194 & 0.2577 & 0.7857 & 1.5037 & 0.3350 & 0.95 \\
\hline & & $0.10-0.20$ & 0.4769 & $5.3201 \times 10^{-6}$ & 0.1992 & 1.1099 & 0.0990 & 0.38 \\
\hline & \multirow{2}{*}{$\mathrm{G}$} & $0.0-0.10$ & 0.5991 & $5.2314 \times 10^{-5}$ & 1.1692 & 1.1455 & 0.1270 & 0.83 \\
\hline & & $0.10-0.20$ & 0.5553 & $1.0906 \times 10^{-5}$ & 0.4736 & 1.1952 & 0.1633 & 0.92 \\
\hline & \multirow{2}{*}{$\mathrm{S}$} & $0.0-0.10$ & 0.5586 & $7.1896 \times 10^{-6}$ & 0.6999 & 1.1490 & 0.1297 & 0.80 \\
\hline & & $0.10-0.20$ & 0.5108 & $1.5039 \times 10^{-5}$ & 0.5131 & 1.1338 & 0.1180 & 0.79 \\
\hline \multirow{6}{*}{ MT } & \multirow{2}{*}{$\mathrm{C}$} & $0.0-0.10$ & 0.6047 & 0.0922 & 0.6220 & 1.3256 & 0.2456 & 0.80 \\
\hline & & $0.10-0.20$ & 0.5167 & $2.2659 \times 10^{-4}$ & 0.5296 & 1.1331 & 0.1175 & 0.77 \\
\hline & \multirow{2}{*}{$\mathrm{G}$} & $0.0-0.10$ & 0.5485 & $1.0799 \times 10^{-5}$ & 1.5805 & 1.0781 & 0.0724 & 0.69 \\
\hline & & $0.10-0.20$ & 0.5382 & $5.2656 \times 10^{-5}$ & 0.3466 & 1.2005 & 0.1670 & 0.73 \\
\hline & \multirow{2}{*}{$\mathrm{S}$} & $0.0-0.10$ & 0.5299 & $2.1350 \times 10^{-5}$ & 0.2180 & 1.2102 & 0.1737 & 0.61 \\
\hline & & $0.10-0.20$ & 0.5449 & $4.0086 \times 10^{-5}$ & 0.7127 & 1.1351 & 0.1190 & 0.70 \\
\hline \multirow{6}{*}{ NT } & \multirow{2}{*}{$\mathrm{C}$} & $0.0-0.10$ & 0.5276 & $7.7775 \times 10^{-7}$ & 0.0880 & 1.0833 & 0.0769 & 0.81 \\
\hline & & $0.10-0.20$ & 0.5841 & 0.2502 & 0.1813 & 1.4878 & 0.3279 & 0.79 \\
\hline & \multirow{2}{*}{ G } & $0.0-0.10$ & 0.5540 & $8.6011 \times 10^{-5}$ & 0.5968 & 1.1258 & 0.1117 & 0.84 \\
\hline & & $0.10-0.20$ & 0.5456 & $7.2213 \times 10^{-6}$ & 0.4363 & 1.2032 & 0.1689 & 0.89 \\
\hline & \multirow{2}{*}{$\mathrm{S}$} & $0.0-0.10$ & 0.5600 & $1.7216 \times 10^{-6}$ & 1.2980 & 1.1042 & 0.0944 & 0.76 \\
\hline & & $0.10-0.20$ & 0.5408 & $2.8309 \times 10^{-5}$ & 0.5640 & 1.1498 & 0.1303 & 0.94 \\
\hline \multirow{6}{*}{ CNT } & \multirow{2}{*}{$\mathrm{C}$} & $0.0-0.10$ & 0.5993 & $1.6587 \times 10^{-5}$ & 0.9049 & 1.1807 & 0.1530 & 0.94 \\
\hline & & $0.10-0.20$ & 0.5636 & 0.0013 & 0.8288 & 1.1725 & 0.1471 & 0.85 \\
\hline & \multirow{2}{*}{$\mathrm{G}$} & $0.0-0.10$ & 0.5404 & $9.6603 \times 10^{-6}$ & 0.6383 & 1.1171 & 0.1048 & 0.79 \\
\hline & & $0.10-0.20$ & 0.5516 & $9.1104 \times 10^{-5}$ & 0.3196 & 1.1987 & 0.1658 & 0.77 \\
\hline & \multirow{2}{*}{ S } & $0.0-0.10$ & 0.5446 & $4.9435 \times 10^{-5}$ & 1.2519 & 1.0908 & 0.0832 & 0.76 \\
\hline & & $0.10-0.20$ & 0.5596 & $2.8989 \times 10^{-5}$ & 0.6501 & 1.1604 & 0.1382 & 0.93 \\
\hline
\end{tabular}

SMS - Soil management system; UR - Use of annual ryegrass; $\theta \mathrm{s}, \theta \mathrm{r}$ - saturation and residual volumetric contents, respectively; $\alpha$, $\mathrm{n}$, $\mathrm{m}$ - adjustment empirical parameters; $\mathrm{R}^{2}$ - coefficient of determination

(1980) equation and this with the Db according to some authors (FIDALSKI; TORMENA, 2007). Therefore, changes in TP and Db are the explanation to the changes that occurred in the van Genuchten (1980) equation parameters, mainly $\theta$ s and $\mathrm{n}$ (Table 3 ).

In CT, NT and CNT (0.0-0.10 m) it was possible to verify very little differences in SWRCs for the $\Psi \mathrm{m}$ different values (Figures 5a, 5e and $5 \mathrm{~g}$ ). This shows that the annual ryegrass used as grazing and silage provokes the same effect in terms of water retention in these systems. In MT the same effect is observed only for the highest potentials, with great difference from
$-10 \mathrm{kPa}$. This result can be ascribed to the basically equal Db, TP, Ma and Mi values (Figures $2 \mathrm{a}, 2 \mathrm{c}, 2 \mathrm{e}$ and $2 \mathrm{~g}$ ) and the clay content that influences water retention in the low $\Psi \mathrm{m}$ region (Figure 2e) (MACHADO et al., 2008; MICHELON et al., 2010).

However, the use of annual ryegrass as cover crop presented important differences in water retention along the whole SWRC (Figures 5a, 5c, 5e and 5g). This result is directly related to differences in the physical properties analyzed for the use of annual ryegrass as cover in relation to other uses and as a result of higher OC content (Figures 2a, 2c, 2e, 2g, 3e and 3g) (MACHADO et al., 2008). 
Figure 5 - Relative differences (RD) between water retention curves from the superficial (0.0-0.10 m) and sub-superficial (0.10-0.20 m) layers of a Haplohumox due to soil management system [conventional (a,b), minimum (c,d), no-tillage (e, f) and chiseled no-tillage $(\mathrm{g}, \mathrm{h})$ ] and the winter crop use [cover crop $(\mathrm{C})$, grazing $(\mathrm{G})$ and silage $(\mathrm{S})$ ]
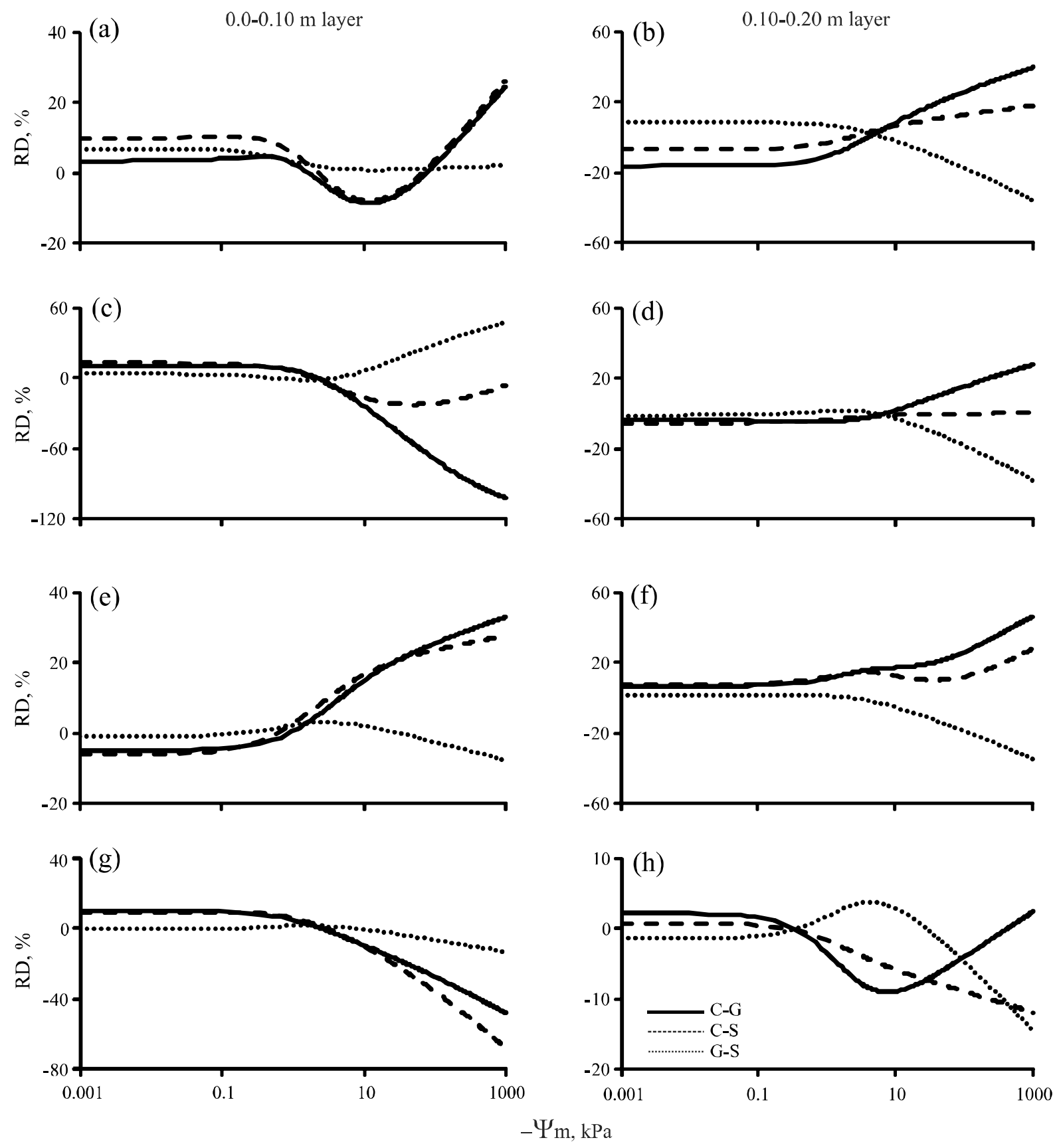

Annual ryegrass used as cover also presents higher difference between water contents in higher and lower $\Psi \mathrm{m}$ in CT, MT and CNT (Figures 4a, 4c and $4 \mathrm{~g}$ ). This indicates higher amount of water available to the plants in this annual ryegrass use in relation to the remaining ones (Figures 6a, 6c and $6 \mathrm{~g}$ ).
Considering the amount of water retained in the soil as a function of pore size up to about $\Psi \mathrm{m}-33 \mathrm{kPa}$ (Figure 6), in the superficial layer, it is possible to see that NT under cover crop (Figure 6e) was the one that presented the worst results for all pore sizes under analysis. TP and Ma reduction might help to explain this result (Figures 2c 
Figure 6 - Water retained (TP- $\theta \mathrm{i})$ as function of the pore radius (r) from the superficial $(0.0-0.10 \mathrm{~m})$ and sub-superficial (0.10$0.20 \mathrm{~m}$ ) layers of a Haplohumox for different soil management systems [conventional (a, b), minimum (c, d), no-tillage (e, f) and chiseled no-tillage $(\mathrm{g}, \mathrm{h})]$ and the winter crop use [cover crop $(\mathrm{C})$, grazing $(\mathrm{G})$ and silage $(\mathrm{S})$ ]
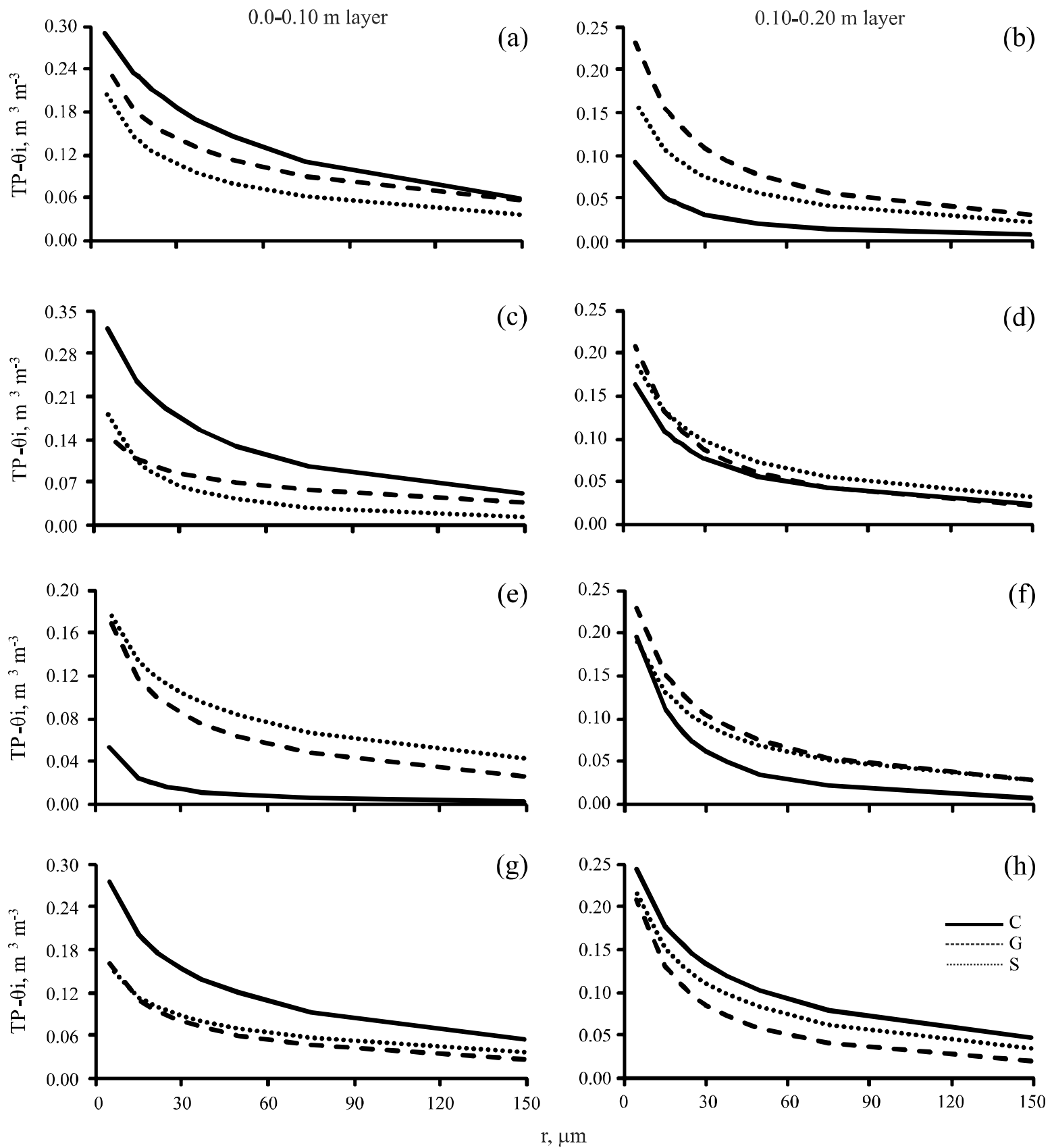

and 2e). However, in other systems this use was the one that presented the best results as it was previously mentioned due to $\mathrm{Db}, \mathrm{TP}$ and Ma values (Figures 2a, 2c and 2e).

In the sub-superficial layer $(0.10-0.20 \mathrm{~m})$, all annual ryegrass uses presented similar behavior regarding water retention in $\mathrm{MT}$ and mainly $\mathrm{CNT}$
(Figures 4d and 4h). Most visible differences occurred between C-G and G-S (Figure 5d) at the lowest $\Psi \mathrm{m}$ in MT. Water retention values near saturation in these two systems were basically the same in all soil uses, which is in agreement with TP values in MT and CNT (Figure 2d). In the SWRC region, in which the soil structure is important, this similarity in SWRC was even more noticeable, this result 
is related to Ma and OC (Figures $2 \mathrm{f}$ and $3 \mathrm{~h}$ ). Values around $\mathrm{Mi}$ also helped to explain the water retention in regions of lower $\Psi \mathrm{m}$ (Figure 2h).

Annual ryegrass used as silage was the one that presented slightly higher water retention for the different pore sizes analyzed when compared to the other uses in MT (Figure 6d). This result is related to the amount of water available to the plants and is similar for all annual ryegrass uses in this management system (Figure 4d). In CNT higher water retention is observed when annual ryegrass is used as cover crop when compared to the other uses (Figure 6h). This result indicates that this use of annual ryegrass might provide better soil structure conditions in terms of water retention to the sub-superficial layer.

In $\mathrm{CT}$, there is higher water retention in macropore related potentials when annual ryegrass is used as grazing and the lowest retention occurs when annual ryegrass is used as cover (Figure 4b). When the potentials became smaller there was an inversion in the SWRC behavior (Figure 5b). However, when the physical properties measured are analyzed (Figures 2 and 3) no differences are seen that can explain the water retention behavior in SWRC. However, in CT and grazing there might be the occurrence of biopores due to the forage root growth resulting from the animal grazing practice on the soil sub-superficial layer (CARVALHO et al., 2010). The appearance of these biopores might be an explanation to the results observed in this use of annual ryegrass.

Regarding water retention for different pore sizes, what was observed in CT was higher retention when annual ryegrass was used as grazing, followed by silage and cover crop (Figure 6b). The cover crop in this management system presented the lowest water retention and this is evidenced by the smallest differences observed between $\theta$ s and $\theta \mathrm{r}$ in SWRC (Figure $4 b$ ). Differences in water retention were more noticeable when the soil pores became smaller, this is due to the differences in water retention for the lowest $\Psi \mathrm{m}$ values between C-G (Figure 5b).

Finally, NT presented the highest water content values when the annual ryegrass was used as cover crop for the whole SWRC in relation to the remaining uses (Figure 4f). When annual ryegrass was used as silage or grazing the water content values were basically the same for the macropore region differing in the micropore region (Figure 5f). These water retention results are not directly related to TP, Ma, clay content or OC content in this management system (Figures 2d, 2f, $3 \mathrm{f}$ and $3 \mathrm{~h}$ ).

Regarding water retention in different pore sizes when the annual ryegrass was used for grazing and silage presented the highest retentions in NT (Figure 6f). The cover crop presented the lowest retentions. However, in SWRC the cover presented higher water content for different $\Psi \mathrm{m}$ (Figure 4f), differences between $\theta$ s and $\theta \mathrm{r}$ were smaller in this use of the annual ryegrass. However, when the pores became smaller there was higher approximation in water retention between the annual ryegrass different uses.

\section{CONCLUSIONS}

1. The intensive use of the soil for the production of anual ryegrass as silage or grazing compared to the use as cover crop, independently of the intensity of soil preparation operations under different management systems (conventional, minimum tillage and chiseled no-tillage), promoted negative effects in the soil bulk density, total porosity and macroporosity;

2 . In the case of the no-tillage management system, mainly at the superficial layer $(0.0-0.10 \mathrm{~m})$, was observed that independent of the use of the ryegrass (silage, grazing or cover) compressive processes promoted increases in its soil bulk density, and, consequently, decreases in its total porosity and macroporosity;

3. For the Haplohumox studied, the water retention suffered more influence of the intensity and the form of the soil preparation opperations than the ryegrass use. However, due to the soil compression, the ryegrass use as silage or grazing promoted an increase in water retention, mainly for conventional and no-tillage management systems.

\section{ACKNOWLEDGEMENTS}

Many thanks are owned to the Brazilian Federal Funding Agencies CNPq and CAPES, the private agencie ABC Foundation for the financial support, scholarships and grants and Dr. Neyde F. B. Giarola for the Soil Physics Laboratory facilities.

\section{REFERENCES}

BATEY, T. Soil compaction and soil management - a review. Soil Use and Management, v. 25, n. 4, p. 335-345, 2009.

BAVOSO, M. A. et al. Preparo do solo em áreas de produção de grãos, silagem e pastejo: efeito na resistência tênsil e friabilidade de agregados. Revista Brasileira de Ciência do Solo, v. 34, n. 1, p. 227-234, 2010.

BELL, L. W. et al. Impacts of soil damage by grazing livestock on crop productivity. Soil and Tillage Research, v. 113, n. 1, p. 19-29, 2011.

BETIOLI JÚNIOR, E. et al. Intervalo hídrico ótimo e grau de compactação de um latossolo vermelho após 30 anos sob plantio 
direto. Revista Brasileira de Ciência do Solo, v. 36, n. 3, p. 971982, 2012.

BRONICK, C. J.; LAL, R. Soil structure and management: a review. Geoderma, v. 124, n. 1-2, p. 3-22, 2005.

CAMARA, R. K.; KLEIN, V. A. Escarificação em plantio direto como técnica de conservação do solo e da água. Revista Brasileira de Ciência do Solo, v. 29, n. 5, p. 789796, 2005.

CANTARELlA, H. et al. Análise química para avaliação da fertilidade de solos tropicais. Campinas: Instituto Agronômico de Campinas, 2001. 285 p.

CARVALHO, P. C. F. et al. Managing grazing animals to achieve nutrient cycling and soil improvement in no-till integrated systems. Nutrient Cycling in Agroecosystems, v. 88 , n. 2 , p. $259-273,2010$.

COSTA, O. V. et al. Estoque de carbono do solo sob pastagem em área de tabuleiro costeiro no sul da Bahia. Revista Brasileira de Ciência do Solo, v. 33, n. 5, p. 1137-1145, 2009.

DANE, J. H. et al. Methods of soil analysis: Part 4 Physical methods. 3. Ed. Madison: Soil Science Society of America, 2002. $1692 \mathrm{p}$.

DORAN, J. W. et al. Defining soil quality for sustainable environment. Madison: Soil Science Society of America, 1994. 244 p.

DREWRY, J. J. et al. Pasture yield and soil physical property responses to soil compaction from treading and grazing: a review. Australian Journal of Soil Research, v. 46, n. 3, p. 237-256, 2008.

EMBRAPA BRASILEIRA DE PESQUISE AGROPECUÁRIA - EMBRAPA. Manual de Métodos de Análise de Solo. 2. ed. rev. atual. Rio de Janeiro: Embrapa Solos, 1997. 212 p.

FALLEIRO, R. M. et al. Influência dos sistemas de preparo nas propriedades químicas e físicas do solo. Revista Brasileira de Ciência do Solo, v. 27, n. 6, p. 1097-1104, 2003.

FIDALSKI, J.; TORMENA, C. A. Funções de pedotransferência para as curvas de retenção de água e de resistência do solo à penetração em sistemas de manejo com plantas de cobertura permanente em citros. Ciência Rural, v. 37, n. 5, p. 1316-1322, 2007.

FREDDI, O. S. et al. Compactação do solo no crescimento radicular e produtividade da cultura do milho. Revista Brasileira de Ciência do Solo, v. 31, n. 4, p. 627-636, 2007.

GIRARDELLO, V. C. et al. Alterações nos atributos físicos de um latossolo vermelho sob plantio direto induzidas por diferentes tipos de escarificadores e o rendimento da soja. Revista Brasileira de Ciência do Solo, v. 35, n. 6, p. 21152126, 2011.

HAMZA, M. A.; ANDERSON, W. K. Soil compaction in cropping systems: A review of the nature, causes and possible solutions. Soil and Tillage Research, v. 82, n. 2, p. 121-145, 2005.
INSTITUTO AGRONÔMICO DO PARANÁ - IAPAR. Cartas climáticas do Paraná: classificação climática - segundo Köppen, 2009. CDROM.

KUNZ, M. et al. Compactação do solo na integração sojapecuária de leite em Latossolo argiloso com semeadura direta e escarificação. Revista Brasileira de Ciência do Solo, v. 37, n. 6, p. 1699-1708, 2013.

LAL, R. Soil quality and agricultural sustainability. Chelsea: Ann Arbor Press, 1998. 378 p.

LANZANOVA, M. E. et al. Atributos físicos do solo em sistema de integração lavoura-pecuária sob plantio direto. Revista Brasileira de Ciência do Solo, v. 31, n. 5, p. 11311140, 2007.

LIPIEC, J. et al. Soil porosity and water infiltration as influenced by tillage methods. Soil and Tillage Research, v. 89, n. 2, p. 210-220, 2006.

MACHADO, J. L. et al. Inter-relações entre as propriedades físicas e os coeficientes da curva de retenção de água de um latossolo sob diferentes sistemas de uso. Revista Brasileira de Ciência do Solo, v. 32, n. 2, p. 495-502, 2008.

MICHELON, C. J. et al. Funções de pedotransferência para estimativa da retenção de água em alguns solos do Rio Grande do Sul. Ciência Rural, v. 40, n. 4, p. 848-853, 2010.

MUALEM, Y. Hydraulic conductivity of unsaturated soils: prediction and formulas. In: KLUTE, A. (Ed.). Methods of Soil Analysis: I. Physical and Mineralogical Methods. Madison: SSSA, 1986. p. 799-823.

R. CORE TEAM. R: A language and environment for statistical computing. R Foundation for Statistical Computing, Vienna, Austria, 2013.

REICHERT, J. M.; SUZUKI, L. E. A. S.; REINERT, D. J. Compactação do solo em sistemas agropecuários e florestais: identificação, efeitos, limites críticos e mitigação. Tópicos em ciência do solo. Viçosa: Sociedade Brasileira de Ciência do Solo, v. 5, p. 49-134, 2007.

SANTOS, H. G. et al. Sistema brasileiro de classificação de solos. Rio de Janeiro: Embrapa Solos, 2013. 353 p.

SEKI, K. SWRC fit - a nonlinear fitting program with a water retention curve for soils having unimodal and bimodal pore structure. Hydrology and Earth System Sciences Discussions, v. 4, n. 1, p. 407-437, 2007.

SILVA, A. P.; KAY, B. D. Estimating the least limiting water range of soils from properties and management. Soil Science Society America Journal, v. 61, n. 3, p. 877-883, 1997.

SILVA, M. A. S. et al. Propriedades físicas e teor de carbono orgânico de um argissolo vermelho sob distintos sistemas de uso e manejo. Revista Brasileira de Ciência do Solo, v. 30, n. 2, p. 329-337, 2006.

SILVA, R. F. et al. Análise conjunta de atributos físicos e biológicos do solo sob sistema de integração lavoura- pecuária. Pesquisa Agropecuária Brasileira, v. 46, n. 10, p. 1277-1283, 2011. 
VAN GENUCHTEN, M. Th. A closed-form equation for predicting the hydraulic conductivity of unsaturated soils. Soil Science Society of America Journal, v. 44, n. 5, p. 892$898,1980$.

VEIGA, M. et al. Soil compressibility and penetrability of an Oxisol from southern Brazil, as affected by long-term tillage systems. Soil and Tillage Research, v. 92, n. 1-2, p. 104113, 2007.

VIANA, E. T. et al. Atributos físicos e carbono orgânico em latossolo vermelho sob diferentes sistemas de uso e manejo. Revista Brasileira de Ciência do Solo, v. 35, n. 3, p. 21052114, 2011. 